\begin{tabular}{c|c|c}
\hline \hline & CLIMATE RESEARCH \\
Vol. 25: 43-54, 2003 & Clim Res & Published October 8 \\
\hline
\end{tabular}

\title{
Examining the ENSO-typhoon hypothesis
}

\author{
James B. Elsner ${ }^{1, *}$, Kam-biu Liu ${ }^{2}$ \\ ${ }^{1}$ Department of Geography, PO Box 2190, The Florida State University, Tallahassee, Florida 32306, USA \\ ${ }^{2}$ Department of Geography and Anthropology, Louisiana State University, Baton Rouge, Louisiana 70803, USA
}

\begin{abstract}
Modern typhoon data and historical documents from Guangdong Province, southern China, are analyzed and found to support the El Niño-Southern Oscillation (ENSO)-typhoon hypothesis. The hypothesis states that tropical cyclone formation during an El Niño event shifts eastward, with typhoons tending to recurve north, staying away from China. From the comprehensive but short modern record, typhoon tracks are grouped into 3 distinct clusters based on geographic position at maximum and terminal typhoon intensities. The majority of typhoons originate between 110 and $170^{\circ} \mathrm{E}$ longitude in the latitude belt between 8 and $25^{\circ} \mathrm{N}$. In general, typhoons take 1 of 3 paths away from this genesis region - a westerly path between latitudes (straight moving), a west-northwesterly path (recurving), or a north-oriented path that keeps them out to sea. Straight-moving typhoons are a significant threat to the Philippines, southern China, and Vietnam, whereas recurving typhoons occasionally threaten Japan, Korea, and northern China. The number of straight-moving typhoons, when grouped by year, is found to be significantly positively correlated with the number of landfalls over China south of the Tropic of Cancer. Thus, the abundance of straight-moving typhoons is a good indicator of the typhoon threat to portions of southern China. Moreover, the number of straightmoving typhoons is correlated with the ENSO cycle. A long annual time-series (1600-1909) of typhoon landfall counts from Guangdong, extracted from historical documents together with treering proxy records of the ENSO cycle, provide data that independently support this relationship.
\end{abstract}

KEY WORDS: Typhoons · Typhoon tracks · ENSO $\cdot$ Guangdong $\cdot$ Southern China $\cdot$ Cluster analysis Resale or republication not permitted without written consent of the publisher

\section{INTRODUCTION}

Economic and human losses associated with the effects of western North Pacific typhoons are immense. High winds, heavy rain, and storm surges bring flood and landslide disasters. The economic loss in China from typhoon-generated storm surges, averaged over the 3 costliest events since 1990, amounts to US $\$ 2.7$ billion (Kentang 2000). Similar annual losses occur in the Philippines and Japan. Understanding environmental conditions that influence tropical cyclone formation, development, and movement is an active area of research (Pan 1981, Gray 1984, Nicholls 1984, Chan 1985, 1994, Revell \& Goulter 1986, Evans \& Allen 1992, Jury 1993, Dong \& Holland 1994, Lander 1994, Elsner et al. 2001).

Approximately one-third of all tropical cyclones originate over the western half of the North Pacific Ocean, making it the most prolific of the tropical cyclone basins. The majority of North Pacific tropical cyclones (and the majority that reach typhoon intensity) occur during June-October. Previous work on the climatology of western North Pacific typhoons has focused on variations in annual frequency (e.g. Wu \& Lau 1992, Chan 1994, Lander 1994, Chan \& Shi 1996, 2000, Chan et al. 1998, Chen et al. 1998, Lander \& Guard 1998, Wang \& Chan 2002). Studies show that the El Niño/Southern Oscillation (ENSO) plays a role in the frequency and distribution of western North Pacific typhoons (Li 1986). While the effect of ENSO on the overall number of typhoons appears to be minor, it tends to create conditions favorable for shifts in the main genesis region.

Numerous climatological studies of typhoon tracks are also available (Harr \& Elsberry 1991, 1995, Chan 1994, Lander 1996, Chan 2000). Periods of specific track type and periods of activity or inactivity are 
related to large-scale atmospheric circulations (Harr \& Elsberry 1995). During El Niño events, when sea surface temperatures (SSTs) in the central and eastern equatorial Pacific are higher than normal, tropical cyclones are relatively more likely to form east of about $160^{\circ} \mathrm{E}$ (Lander 1994). Chan (1985) notes that typhoons tend to form farther east during El Niño events and are consequently more likely to track to the east of China. This we refer to as the 'ENSO-typhoon' hypothesis. The corollary is that typhoons are relatively more likely to affect China during La Niña years (Saunders et al. 2000). Studies of North Atlantic hurricanes indicate an inverse relationship between major hurricanes affecting the Gulf Coast and those affecting the East Coast of the United States (Liu 1999, Elsner et al. 2000a). There is speculation on a similar inverse relationship across latitudes in typhoon activity (Liu et al. 2001).

Modern observational records of tropical cyclones are generally too short to reliably associate climate factors with landfall probabilities over specific regions. Recent geological and historical studies have uncovered new information related to past tropical cyclone events, spawning the field of 'paleotempestology' (Liu \& Fearn 1993, 2000, Donnelly et al. 2001). In particular, the abundance of historical documentary records from the Guangdong Province in southern China (Chan \& Shi 2000, Liu et al. 2001) provides a unique opportunity to examine the ENSO-typhoon hypothesis.

In this paper we analyze the modern typhoon record from the western North Pacific region along with annual typhoon counts extracted from Guangdong historical documents in an attempt to better understand the relationship of climate to catastrophic typhoon events. The modern record allows us to group typhoon tracks and relate track types to ENSO. These relationships are then considered in light of the long historical record from Guangdong. Specifically, we first use the modern record, starting with 1945, to establish track types and landfall frequencies. Next we show a statistical relationship between landfalls, track types, and ENSO. Results are consistent with the ENSO-typhoon hypothesis, and they underscore the importance of ENSO in modulating the odds of coastal typhoon activity in this populous part of the world.

\section{DATA}

The study makes use of (1) modern typhoon track data for the entire western North Pacific, (2) instrumental records of climate indices, (3) historical typhoon records from Guangdong, and (4) paleoclimatic proxy records of ENSO. Modern track data were obtained from the Unisys Corporation website. The data consist of $6 \mathrm{~h}$ positions (latitude and longitude in tenths of a degree) and intensities (5 knot intervals of maximum wind speed) for all western North Pacific tropical cyclones based on Annual Tropical Cyclone Reports issued by the Joint Typhoon Warning Center (JTWC) on Guam. The western North Pacific extends westward from the international dateline. The reports contain a post-season assessment of the position and intensity for all cyclones warned upon by the JTWC during the year (Lander 1994). Wind speeds used by the JTWC to define the intensities in tropical cyclones are the over-water, maximum-sustained, 1 min average wind velocities at a reference level of $10 \mathrm{~m}$ above the surface. Data are most reliable since satellite imagery became routinely available in the late 1960s.

A reliable time record of the Pacific ENSO is obtained by using basin-scale equatorial fluctuations of SSTs. Average SST anomalies over the region bounded by $6^{\circ} \mathrm{N}$ to $6^{\circ} \mathrm{S}$ and 90 to $180^{\circ} \mathrm{E}$ are called the 'cold tongue index' (CTI) (Deser \& Wallace 1990). The data employed for 1849-1997 is from the International Comprehensive Ocean Atmosphere Data Set (ICOADS), version 2, and for 1998-2002 from the National Centers for Environmental Prediction (NCEP) real-time marine data. Along with ENSO we consider 2 additional climate indices.

The Pacific decadal oscillation (PDO) is a persistent El-Niño-like pattern of Pacific climate variability. A PDO index (PDOI) is defined as the leading principal component of North Pacific monthly SST variability (poleward of $20^{\circ} \mathrm{N}$ ). The monthly mean global average SST anomalies were removed to separate this pattern of variability from any 'global warming' signal. While the ENSO and PDO have similar spatial climate patterns, they have different behavior in time (Mantua et al. 1997). The climatic signature of the PDO is most apparent over the North Pacific Ocean and North America (Zhang et al. 1997). Monthly values of the CTI and PDOI were obtained from the Joint Institute for the Study of the Atmosphere and the Oceans website. The CTI is strongly correlated with other ENSO SST indices. Therefore results presented within should not be sensitive to this choice.

The North Atlantic Oscillation index (NAOI) is defined as the normalized pressure difference between the Azores and Iceland. The NAO is correlated with the frequency of tropical cyclones worldwide (Elsner \& Kocher 2000), the frequency of major hurricane activity over the North Atlantic (Elsner et al. 2000b), and the occurrence of hurricanes along the southern US coast (Jagger et al. 2001, Elsner et al. 2001). Values of the NAOI, as calculated from Gibraltar and a station over southwest Iceland (Jones et al. 1997), are obtained from the Climatic Research Unit of the University of East Anglia, Norwich, UK. 
A portion (1600-1909) of the reconstructed 1000 yr time-series of typhoon landfalls from Guangdong provides a key data set to the present study. Data were compiled from Fang Zhi (semiofficial local gazettes) and are based on detailed evaluations of Chinese historical records (Liu et al. 2001). Reconstructions of past climate conditions from tree-ring chronologies were obtained online from the NOAA Paleoclimatology Program. Annually resolvable records of the ENSO (Cook 2000) before the turn of the twentieth century are used. Reconstruction of the ENSO variability for December-February each year are based on tree ring data from northern Mexico and Texas. The reconstruction uses factor scores from a principal component analysis. Chronologies are compiled from indices of tree growth (early wood or total ring width) de-trended to remove biological influences. The December-February proxy values are compared with lagged (May-December) typhoon counts from Guangdong.

\section{TYPHOONS IN THE MODERN RECORD}

\subsection{Summary statistics}

Here we analyze characteristics of the recorded typhoons occurring over the western North Pacific during 1945-2002, inclusive. Although we present no new findings in this section, it provides the context for our later analysis of the historical Guangdong typhoon records (Chan \& Shi 2000). A typhoon is defined as a tropical cyclone that has sustained $1 \mathrm{~min}$ wind speed of at least 64 knot. This is consistent with the definition of hurricanes over the eastern North Pacific and North Atlantic regions (Elsner \& Kara 1999). Table 1 shows the summary statistics based on 1002 typhoons over the 58 yr period. Four of the typhoons had missing intensity estimates. The columns in the table are independent. The mean latitude of typhoon origin (dissipation) is $17.0^{\circ} \mathrm{N}\left(26.0^{\circ} \mathrm{N}\right)$. The mean longitude of origin (dissipation) is $136.9^{\circ} \mathrm{E}\left(131.3^{\circ} \mathrm{E}\right)$.

Comparing typhoon positions from the pre-(1945 -1970) and post-(1971-2002) satellite eras, we find no statistically significant difference in locations. However, the pre-satellite era maximum intensities are found to be marginally significantly higher (by 4.4 knot). The mean pre-satellite era maximum intensity is 106.1 knot, which compares to a mean post-satellite era maximum intensity of $101.7 \mathrm{knot}$. A Student's $t$ test on the difference in means results in a p-value of
0.013, providing suggestive evidence of an intensity difference. This intensity difference before and after 1970 is noted in Bouchard (1990) and Black (1993). Both indicate that it is likely an artificial bias. Yet, aircraft reconnaissance was nearly routine into western North Pacific tropical cyclones during 1945-1988. Aircraft data provide an accurate measure of the minimum pressure, which can be used to estimate the maximum wind intensity. As our analysis is concerned with typhoon locations, this intensity bias (whether artificial or natural) will not seriously affect the results.

Examining initial and final positions, there is clear divergence of tracks near the coast of China. Most typhoons originate between the parallels of 5 and $25^{\circ} \mathrm{N}$ and the meridians of 120 and $160^{\circ} \mathrm{E}$, and they develop within the low-level monsoon trough of pressure. The current hypothesis is that during El Niño years the monsoon trough extends farther east, allowing typhoons to form farther east, whereas during La Niña years stronger easterly trades dominate the low latitudes of the western North Pacific and keep the monsoon trough and typhoon genesis region near or to the west of its typical location (Lander 1994).

The general track of a developing typhoon is toward the WNW of the place of origin, especially when the monsoon trough is in its mean NW-SE orientation (Lander 1996). Recurvature describes a track that begins with a WNW heading but becomes more northerly as it advances. This clockwise turning varies from nearly absent to storms that eventually head toward the east (almost $180^{\circ}$ from the initial heading). And on occasion, when the monsoon trough extends farther north and east than normal and acquires a reverse SW-NE orientation, typhoon motion is more northerly (Lander 1996). Large-scale atmospheric flow features that direct typhoon recurvature include an eastward retreating subtropical ridge of high pressures and an approaching trough in the middle-latitude, upper-level westerlies. 


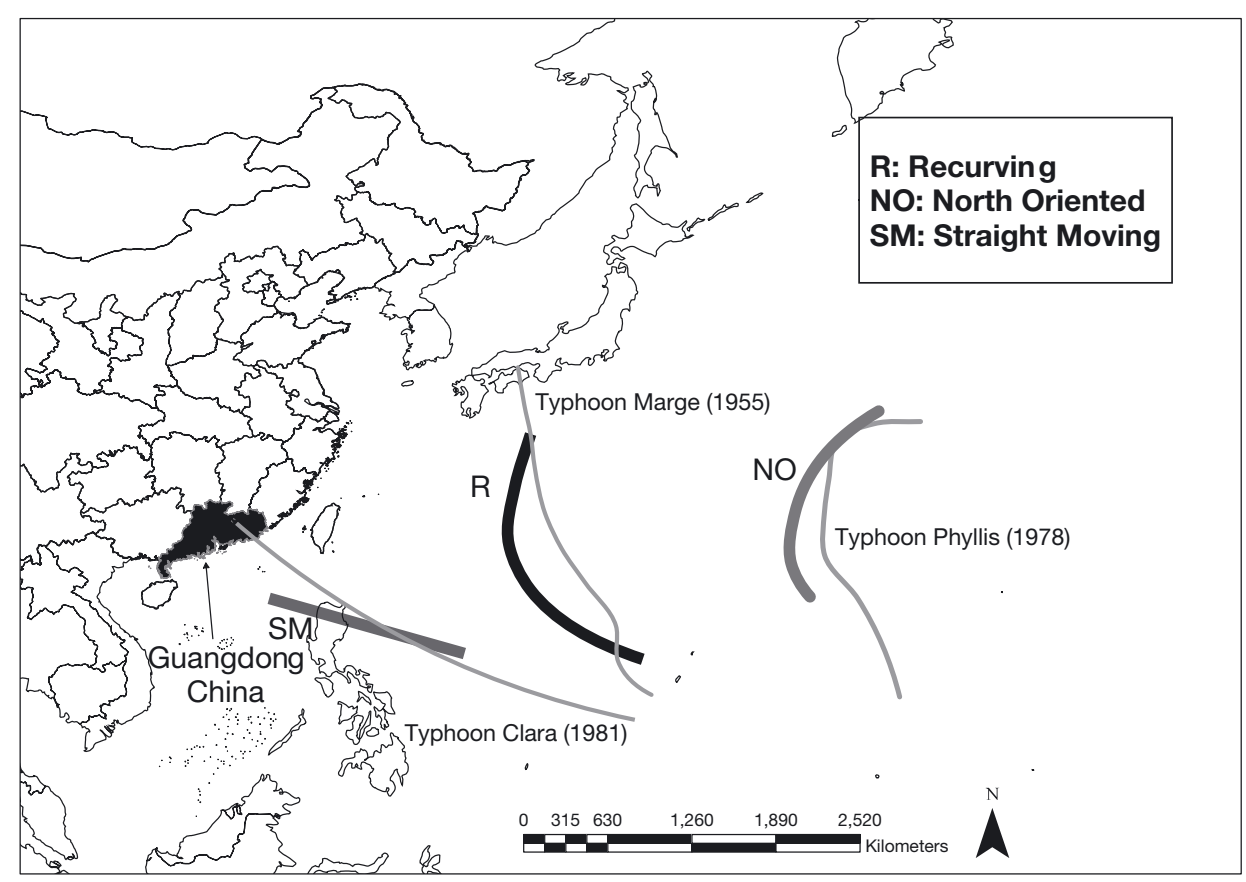

Fig. 1. Tropical cyclone paths (thin lines) for typhoons Clara, Marge, and Phyllis as examples of the 3 track types. Track type is based on a $k$-means cluster analysis. Bold lines indicate the average track of the straight-moving (SM), recurving (R), and northoriented (NO) typhoons based on average latitude and longitude positions at initial, maximum, and final typhoon intensities

\subsection{Typhoon track types}

A tropical cyclone is steered by the environmental flow in which it is embedded. To a significant extent, the deep-layer $(\sim 300-850 \mathrm{mb})$ mean flow out to a radius of ca. $300 \mathrm{~km}$ from the cyclone's center defines the storm's motion (Franklin et al. 1996). On short time scales, the deep layer mean flow is associated with the positioning and strength of the subtropical high. The low and middle tropospheric flow patterns also are influenced by circulations of planetary scale, which have inter-annual to multi-decadal variations. Thus, typhoons may show preferred paths on these time scales as well. During particular years, typhoons have a tendency to remain at low latitudes, whereas during other years the tendency may be for typhoons to track northward. Convective feedback processes within the typhoon and near-typhoon environment through advection of upper-level divergence may contribute to typhoon recurvature (Krishnamurti et al. 1992).

To better associate climate factors with typhoons over southern China, it is important to identify general track types. This is accomplished with the help of a $k$-means cluster analysis. Cluster analysis is an automated search procedure that identifies groups of observations that are cohesive and separated by other groups. The purpose is to classify data of previously unknown structure. Based on recent work (Sandgathe 1987, Harr \& Elsberry 1991, Lander 1996), we suggest that typhoon tracks fall into 1 of 3 groups. The $k$-means clustering method is based on iterative relocation in which data values are moved from one group to another until there is no additional improvement in the sum-of-squares criterion. Group membership is determined by calculating the centroid for each group. The centroid is the multidimensional version of the mean. Each typhoon is assigned to a group with the closest centroid (MathSoft 1999). The $k$ refers to the a priori specification of the number of groups, here set to a value of 3.

Four variables are used in the cluster analysis: (1) latitude and (2) longitude of the typhoon at maximum intensity, and (3) latitude and (4) longitude of the typhoon at final typhoon intensity. Initial positions are not used, as our focus is on coastal typhoon activity. Three unique characteristics of the present classification are the exclusion of tropical storms, the inclusion of typhoons over the South China Sea, and the use of an objective classification scheme (cluster analysis). Results of the clustering are summarized in Table 2. Fig. 1 shows the mean tracks for the 3 typhoon groups based on their average initial, maximum intensity, and final typhoon positions. Shown are examples of each track type based on the $6 \mathrm{~h}$ positions over the lifetime of the tropical cyclone. As anticipated, the analysis 
Table 2. Typhoon statistics by track type. Track types are determined from a $k$ means cluster analysis using typhoon positions at maximum and final typhoon intensities (see text)

\begin{tabular}{|lcrr|}
\hline Statistic & $\begin{array}{c}\text { Straight-moving } \\
\text { typhoons }\end{array}$ & $\begin{array}{c}\text { Recurving } \\
\text { typhoons }\end{array}$ & $\begin{array}{c}\text { North-oriented } \\
\text { typhoons }\end{array}$ \\
\hline Total number & 409 & 378 & 215 \\
Average first latitude $\left({ }^{\circ} \mathrm{N}\right)$ & 15.44 & 17.51 & 18.98 \\
Average MI latitude $\left({ }^{\circ} \mathrm{N}\right)$ & 17.37 & 21.17 & 22.79 \\
Average last latitude $\left({ }^{\circ} \mathrm{N}\right)$ & 19.77 & 28.99 & 32.84 \\
Average first longitude $\left({ }^{\circ} \mathrm{E}\right)$ & 126.29 & 138.76 & 153.71 \\
Average MI longitude $\left({ }^{\circ} \mathrm{E}\right)$ & 120.71 & 134.36 & 151.24 \\
Average last longitude $\left({ }^{\circ} \mathrm{E}\right)$ & 115.63 & 134.23 & 156.13 \\
Average MI (knot) & 99.4 & 108.1 & 104.1 \\
\hline
\end{tabular}

On average, straight-moving typhoons form farther south and west of the recurving typhoons, partly due to the fact that a subset of the straightmoving typhoons form over the South China Sea, west of the Philippines. The latitudinal separation between the first and last positions for straightmoving typhoons is less than $5^{\circ}$ on average. This compares with more than $11^{\circ}$ on average for both recurving and north-oriented typhoons. The average maximum intensity of straight-moving typhoons is less than that for recurving typhoons, whereas the average time at

provides distinct typhoon track types including straight-moving, recurving, and north-oriented. A distinguishing feature of the typhoon tracks is their change in longitudinal position. Straight-moving typhoons tend to remain on a general westerly course, while recurving and north-oriented typhoons tend to move toward higher latitudes.

The objective cluster analysis produces a grouping of western North Pacific typhoon tracks that resembles a synthesis of the subjective classifications presented elsewhere. This is particularly true of the straightmoving storms. For instance, Lander (1996) remarks that most typhoons move WNW, beginning at low latitude, with about one-third continuing on this track before making a landfall in east Asia, south of about $25^{\circ} \mathrm{N}$. This typical track is captured by our straightmoving typhoons. The term 'straight moving' is used to describe tropical cyclones that move on long, uncomplicated west to northwesterly paths from their place of origin to landfall in southeast Asia or southern China (Sandgathe 1987). On an annual basis, we find that the frequency of straight-moving typhoons is significantly correlated $(\mathrm{r}=0.66)$ with the frequency of straightmoving tropical cyclones previously identified (Lander 1996)

The typhoons identified here as recurving and northoriented also tend to represent those previously classified as such (Lander 1996), although there are exceptions. For instance, a typhoon that travels NW toward Japan, and then NE would be classified as a recurving typhoon (Lander 1996), but it might be classified as a north-oriented typhoon in our scheme, depending on how far east it travels as a typhoon. Furthermore, some typhoons classified by our cluster analysis as recurving, might be better classified as north-oriented according to previous heuristics (Lander 1996). Since our primary interest here is the typhoons that affect Guangdong, the relevant track type is straight moving, for which there is good agreement with previous research. typhoon intensity is shortest for the straight-moving typhoons, because they reach the coast quicker (and thus weaken quicker). These 2 facts are related, as the group of straight-moving typhoons includes the shorter-lived tropical cyclones of the South China Sea.

The annual average number of straight-moving typhoons over 1945-2002 is 7.1; this compares with annual averages of 6.5 and 3.7 for recurving and northoriented typhoons, respectively. The year-to-year variation in typhoon counts is seen in Fig. 2. Straightmoving typhoons are most frequent, with annual counts ranging from a minimum of 0 (in 2002) to a maximum of 17 (in 1964). Annual counts of recurving typhoons range from a minimum of 2 (in 1975 and 1977 ) to a maximum of 13 (in 1958). None of the time series show a significant lag-1 autocorrelation; however, there appears to be some anti-correlation between the annual frequencies of straight-moving and recurving typhoons $(\mathrm{r}[\mathrm{SM}, \mathrm{R}]=-0.37)$. This anticorrelation is similar to the negative correlation found in major hurricane activity between the US East Coast and Gulf Coast (Elsner et al. 2000a).

To examine this inverse relationship in typhoon activity across latitudes, Fig. 3 shows the annual counts of recurving versus straight-moving typhoons. Overall, there appears to be a weak negative relationship. The best-fit straight line explains $14 \%$ of the variation and the $\mathrm{p}$-value on the slope is 0.004 , providing convincing evidence against the null hypothesis that the slope is zero (no relationship).

The anti-correlation in the abundance of straightmoving versus recurving typhoons hints at a largescale mechanism for changes in landfall probability. A similar suggestion was made based on hurricane landfalls in the United States (Elsner \& Kara 1999). For major North Atlantic hurricanes, a possible mechanism is the mean position of the subtropical high (Liu \& Fearn 2000, Elsner et al. 2000a). When the subtropical high is located farther west and south, hurricanes are more apt to affect the Gulf Coast and avoid the East 

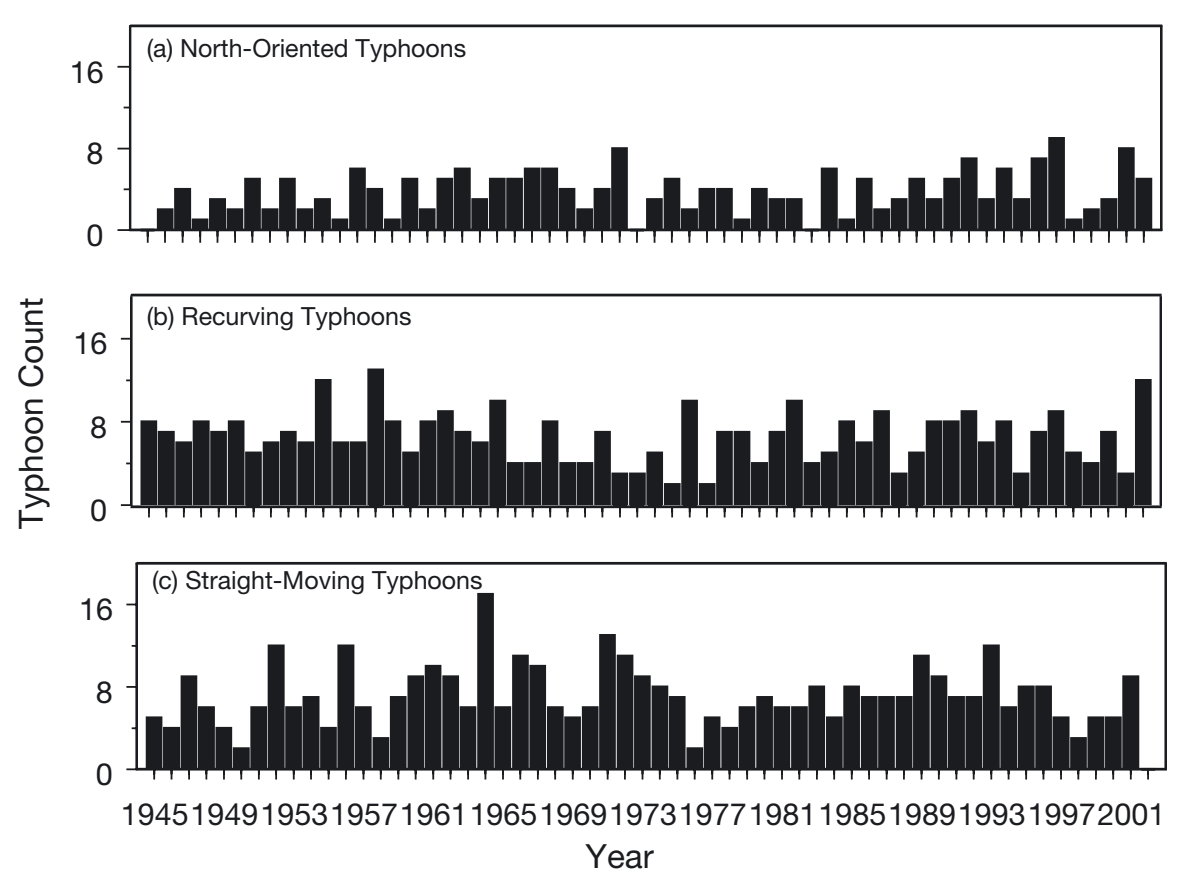

Fig. 2. Time series of annual numbers of western North Pacific typhoons by track type over 1945-2002

Coast. Another possible mechanism involves changes in SST. The inverse relationship is also consistent with a track-shift hypothesis (Liu et al. 2001). No association is found between annual counts of straight-moving and north-oriented typhoons or between annual counts of recurving and north-oriented typhoons.

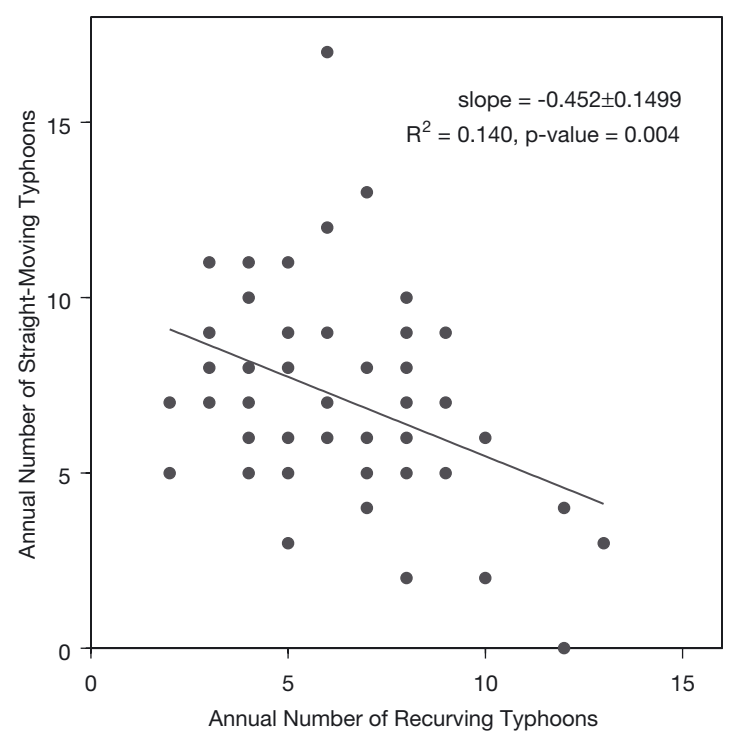

Fig. 3. Annual number of recurving vs straight-moving typhoons. The line indicates the ordinary least-squares best fit. The slope and SE along with the $\mathrm{R}^{2}$ and $\mathrm{p}$-value are given in the figure

\subsection{Typhoons in southern China and Japan}

Terminal positions, representing the last $6 \mathrm{~h}$ report of typhoon intensity for the tropical cyclone, of the 1002 typhoons are shown in Fig. 4. Straight-moving typhoons threaten the Philippines, Vietnam, and southern China. In contrast, recurving hurricanes tend to threaten Japan and Korea. North-oriented typhoons tend to remain offshore with little or no threat to the mainland. The association of track type with landfall potential makes this classification useful for examining climate factors responsible for landfall threat.

For tropical cyclones that approach land, the $6 \mathrm{~h}$ records provide a position and intensity before and after the storm crosses the coastline. Landfalls are estimated by considering all storms that have an intensity of at least 64 knot immediately before crossing the coast. The purpose of the landfall analysis is to examine and compare the relationships between annual occurrence of typhoons of a specific track type with those making landfall over southern China south of the Tropic of Cancer and over Japan.

Fig. 5 shows scatter plots describing the relationships between the annual number of recurving and straight-moving typhoons to the annual number of Japan and south China landfalling typhoons. A landfalling typhoon is a tropical cyclone that makes at least 1 landfall at typhoon intensity. The plots indicate weak or no relationship between recurving 


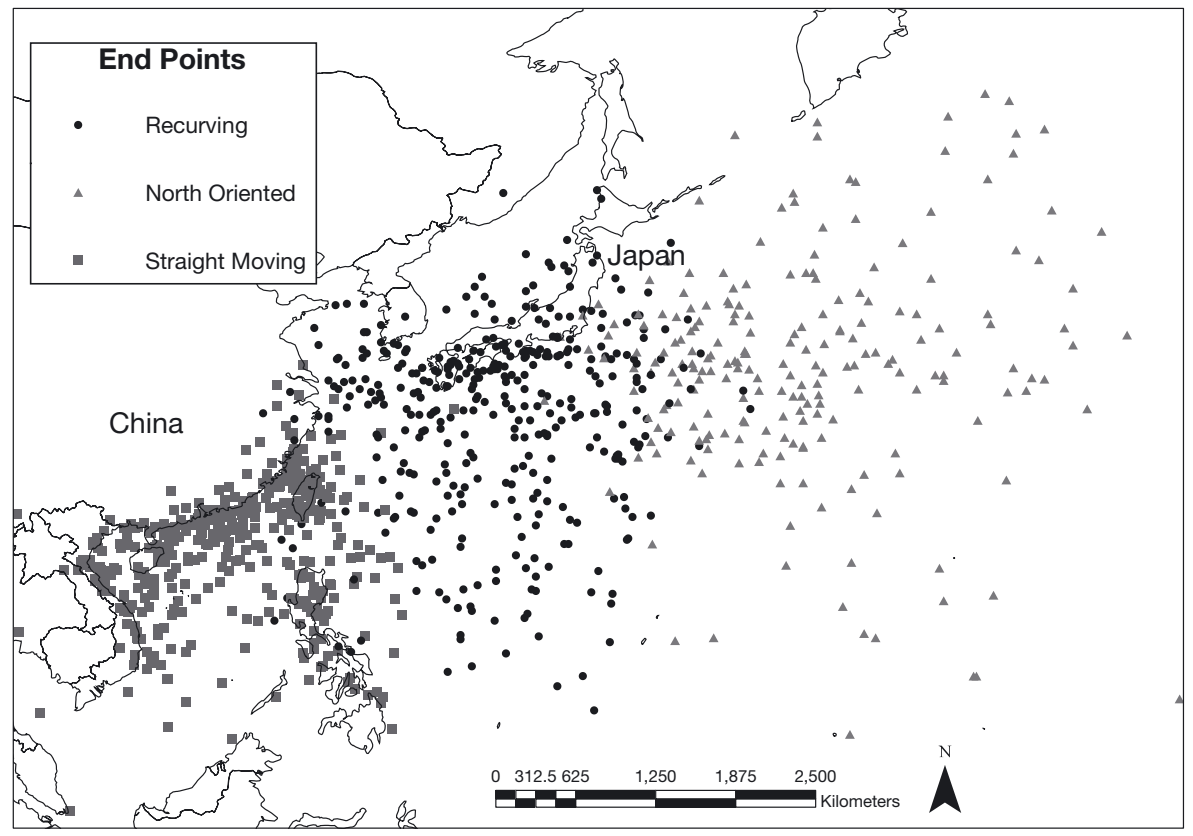

Fig. 4. Terminal positions of all 1002 typhoons (1945-2002) by track type

typhoons and south China landfalls and between straight-moving typhoons and Japan landfalls. Positive relationships are noted between recurving typhoons and Japan landfalls and between straightmoving typhoons and south China landfalls. The association appears to be strongest for this latter case. Years with an above normal number of straight-moving (recurving) typhoons are years of greater landfall probability for southern China (Japan).

The relationships are quantitatively confirmed using linear regression models. A model for the mean number of Japan typhoons that uses the number of recurving typhoons as the single predictor results in a p-value of 0.006 on the slope parameter. The $p$-value provides strong evidence that the slope is different from zero. More significantly, a model for the mean number of south China typhoons that uses the number of straight-moving typhoons as the predictor produces a $\mathrm{p}$-value that is less than 0.0001 . Thus, a model that accurately predicts the annual count of straight-moving typhoons could be used to specify landfall probabilities in southern China.

\subsection{Relationships between track type and climate}

Typhoon landfalls are contingent events. Influenced to a large degree by atmospheric steering mechanisms,
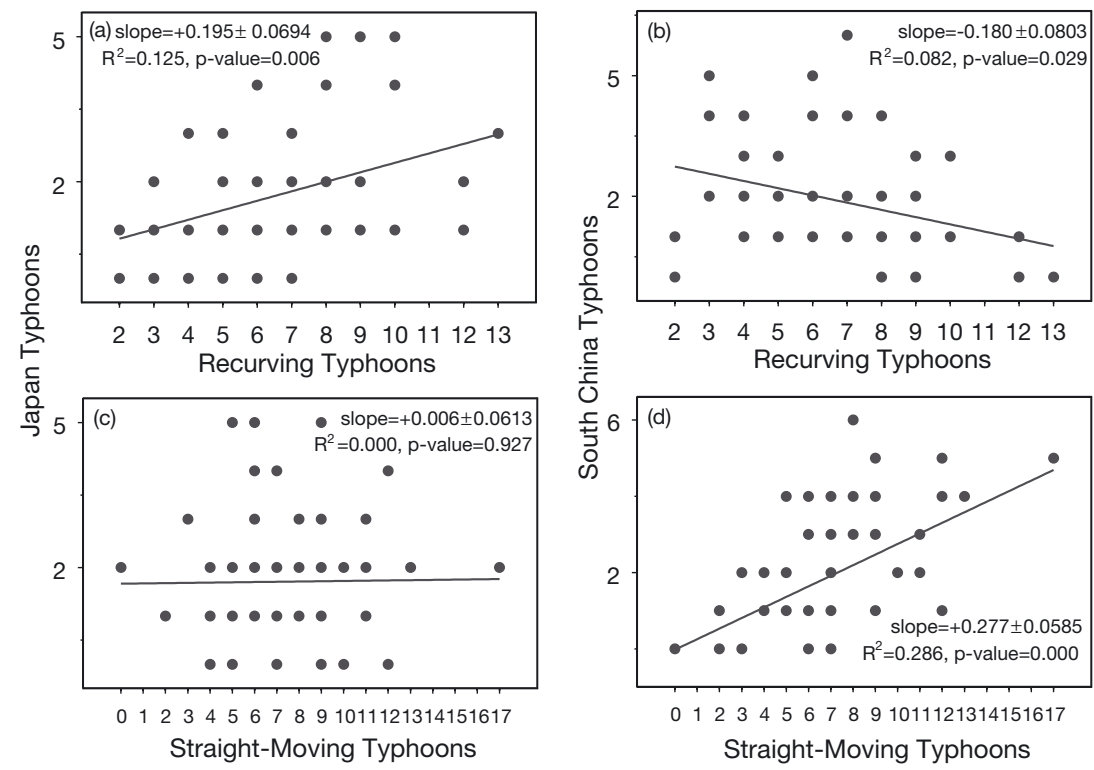

Fig. 5. Annual number of Japan and south China typhoons vs recurving and straight-moving typhoons. (a) Japan vs recurving, (b) south China vs recurving, (c) Japan vs straight-moving, and (d) south China vs straight-moving. Lines indicate the best linear fit. Slope values and standard errors along with $\mathrm{R}^{2}$ and p-values corresponding to the best fit are given in each panel 
a straight-moving typhoon will head toward the coast. However, whether or not it makes landfall depends on subtle factors unrelated to steering or development mechanisms. A typhoon heading for southern China, for instance, may lose much of its intensity as it strikes the Philippines. Or, a typhoon heading for Japan may recurve just enough to spare the islands. The occurrence of typhoons in Guangdong is influenced by the location of Taiwan relative to the predominant typhoon track. The interaction of the typhoon circulation with the complicated topography associated with Taiwan's central mountain range can lead to track deflection and changes in intensity (Wu \& Kuo 1999). This factor is unrelated to the general atmospheric steering currents. Thus in trying to understand climate factors related to landfalls, particularly in short time records, grouping tracks by type provides a broader spatial resolution that reduces the amount of contingency inherent in annual landfall counts.

The strong statistical relationship between annual occurrences of straight-moving typhoons and southern China landfalls and between annual occurrences of recurving typhoons and Japan landfalls allows us to use the frequency of these track types as indices of landfall threat. That is, years conducive to straightmoving typhoons will be years of greater landfall threat to Guangdong. The leading modes of climate variability include ENSO, NAO, and PDO. We consider the occurrence of typhoons by track type when grouped by years exhibiting extremes of these climate modes. The climate modes are characterized by indices representing 3 mo averages from August through October, and extremes are considered as the lowest and highest 20 values of the index during 1945-2002, inclusive.
Table 3 shows the comparison of typhoon activity relative to the 3 climate indices. Typhoon statistics are compiled for 2 groups of years for each index representing the upper and lower terciles of ENSO, NAO, and PDO. Results show that during years of high values of the CTI (El Niño) the average number of straight-moving typhoons is 6.3. This compares to an average of 7.6 during La Niña years (low values of the CTI). The relationship between track frequency and ENSO is opposite for recurving and north-oriented typhoons. Typhoons with recurving tracks are more common during El Niño years. These results are consistent with an eastward displacement of tropical cyclone origins during El Niño years. Typhoons that form farther east tend to recurve away toward higher latitudes. During La Niña years, in contrast, typhoons developing farther west tend to move straight in the direction of southern China, as implied by the ENSOtyphoon hypothesis. Here we are unable to determine whether the changes associated with the ENSO cycle relate only to genesis regions or whether they also play a role in the overall steering flow.

Only minor differences are noted when activity is grouped by values of the NAO index. Moreover, the annual number of typhoons appears to be statistically unrelated to values of the PDO. We tested for differences in means between the 2 periods using a Wilcoxon signed-rank test. Table 3 shows the p-values based on the large-sample approximation for the null hypothesis of no difference against the one-sided alternative. In general, values indicate little evidence against the null hypothesis of equal typhoon activity. The exception is ENSO, where we find significantly more north-oriented typhoons during El Niño events. Seasonal variation in typhoon genesis regions is a

Table 3. Typhoon statistics by track type grouped by upper and lower tercile values from indices of ENSO, NAO, and PDO. SM: straight-moving, R: recurving, NO: north oriented. The ENSO variable is the value of the cold tongue index (CTI). The CTI is based on sea-surface temperatures (SSTs) over the equatorial Pacific region. The NAO variable is the value of the pressure difference between Iceland and Gibraltar. The PDO is the lead principal component of SSTs over the extra-tropical regions of the North Pacific Ocean. Index values are averaged over the 3 mo of August-October

\begin{tabular}{|c|c|c|c|c|c|c|c|c|c|}
\hline \multirow[t]{2}{*}{ Statistic } & \multicolumn{3}{|c|}{ ENSO } & \multicolumn{3}{|c|}{ NAO } & \multicolumn{3}{|c|}{ PDO } \\
\hline & $\mathrm{SM}$ & $\mathrm{R}$ & NO & SM & $\mathrm{R}$ & $\mathrm{NO}$ & SM & $\mathrm{R}$ & $\mathrm{NO}$ \\
\hline & \multicolumn{3}{|c|}{20 coldest years } & \multicolumn{3}{|c|}{20 weakest years } & \multicolumn{3}{|c|}{20 coldest years } \\
\hline Total no. & 152 & 120 & 52 & 157 & 134 & 86 & 153 & 119 & 65 \\
\hline Maximum & 17 & 12 & 6 & 17 & 12 & 9 & 17 & 12 & 8 \\
\hline \multirow[t]{2}{*}{ Average } & 7.6 & 6.0 & 2.6 & 7.8 & 6.7 & 4.3 & 7.6 & 6.0 & 3.2 \\
\hline & \multicolumn{3}{|c|}{20 warmest years } & \multicolumn{3}{|c|}{20 strongest years } & \multicolumn{3}{|c|}{20 warmest years } \\
\hline Total no. & 127 & 147 & 89 & 142 & 142 & 74 & 127 & 147 & 76 \\
\hline Maximum & 12 & 12 & 9 & 13 & 13 & 7 & 12 & 13 & 9 \\
\hline \multirow[t]{2}{*}{ Average } & 6.3 & 7.4 & 4.4 & 7.1 & 7.1 & 3.7 & 6.4 & 7.4 & 3.8 \\
\hline & \multicolumn{3}{|c|}{ Average difference } & \multicolumn{3}{|c|}{ Average difference } & \multicolumn{3}{|c|}{ Average difference } \\
\hline Z-value & 1.014 & -1.747 & -2.730 & 0.612 & -0.723 & 0.602 & 0.777 & -0.649 & -0.877 \\
\hline$p$-value & 0.310 & 0.081 & 0.006 & 0.540 & 0.470 & 0.547 & 0.437 & 0.099 & 0.381 \\
\hline
\end{tabular}


likely factor in limiting the statistical significance of these results (Chan 2000), consistent with the ENSOtyphoon hypothesis.

\section{HISTORICAL TYPHOON RECORD}

The negative correlation between annual numbers of straight-moving and recurving typhoons supports the notion of large-scale climate patterns differentially influencing landfall probabilities. Analysis of typhoon activity stratified by the dominant climate modes suggests that ENSO might play a role in this seesaw pattern. In particular, results indicate that during El Niño conditions, typhoons are more likely to recurve and stay north and east of China. In contrast, typhoons during La Niña conditions are more likely to change little in latitude and threaten southern China. This is consistent with the finding that typhoon landfalls are more common in the northern Philippines and over the South China Sea during La Niña years (Saunders et al. 2000).

Typhoons of the western North Pacific typically originate along the axis of the low-level monsoon trough within an area of weak cyclonic rotation (Lander 1994, Chia \& Ropelewski 2002). On average during the summer months (July-September), the monsoon trough extends from near Taiwan southeastward to a terminus near $10^{\circ} \mathrm{N}, 150^{\circ} \mathrm{E}$ (SE of Guam). The terminus of the trough is defined as the eastward extent of winds that have a westerly component equatorward of the trough axis. During El Niño years when the waters of the central equatorial Pacific are warmer than normal, the trough extends farther east. Above-normal tropical storm activity in the eastern part of the western North Pacific during El Niño years is well known (Ramage \& Hori 1981, Chan 1985, Dong \& Holland 1994). Typhoons originating farther east are more likely to recurve toward higher latitudes.

Historical typhoon landfall counts to the year 1909 over Guangdong together with tree-ring proxy records of the ENSO allow us to independently verify these results. Annual typhoon counts are likely underestimated prior to 1600 (Liu et al. 2001), so the analysis is performed on the historical counts over 1600-1909. As mentioned, typhoon landfall events are contingent, and not all years in which the climate is favorable for straight-moving typhoons will result in landfalls over southern China. Consequently long records of landfalls, such as those from Guangdong, are necessary for determining the influence of climate on regional landfall rates.

A stratification of years based on extremes of the tree-ring reconstructed ENSO SST (Cook 2000) shows that the average annual number of Guangdong landfalls during the 20 coldest years is 1.9, compared with 1.2 during the 20 warmest years (Table 4). Note that the ENSO SST proxy values represent a December-February average and are located in time based on the year of December. Since ENSO tends to reach its peak in the boreal winter, it has its greatest impact on typhoons during the previous summer and fall. The difference in typhoon rates is consistent with results from the modern record, which show a greater likelihood of landfalls in southern China under La Niña conditions. The grand mean is 1.5 typhoons $\mathrm{yr}^{-1}$, thus El Niño (La Niña) events decrease (increase) the typhoon rate below (above) climatology. Assuming the annual typhoon rate follows a Poisson distribution under both El Niño and La Niña events, Fig. 6 shows the annual probability distribution under extremes of the ENSO cycle. Multiple landfalls are more probable during La Niña than during El Niño.

The effect of ENSO on the occurrence of typhoons over southern China is likely modulated by other factors related to conditions that influence overall typhoon formation over the basin. This is similar to hurricane activity over the North Atlantic, where factors related to overall hurricane frequency (Gray 1984, Landsea et al. 1992, Goldenberg et al. 2001) tend to be separate from factors related to tracks (Elsner et al. 2001).

Table 4. Guangdong (GD) typhoons by year. Years are the 20 warmest and 20 coldest based on annual tree-ring chronologies as an index for ENSO sea surface temperature (SST) over 1600-1909. The proxy values represent a DecemberFebruary average and are placed on the December year, i.e. 1747 represents December $1747-F e b r u a r y ~ 1748$, and the typhoon counts are for May-December 1747

\begin{tabular}{|c|c|c|c|c|c|}
\hline \multicolumn{3}{|c|}{20 coldest years } & \multicolumn{3}{|c|}{20 warmest years } \\
\hline Year & $\begin{array}{l}\text { ENSO } \\
\text { proxy }\end{array}$ & $\begin{array}{c}\text { GD } \\
\text { typhoon }\end{array}$ & Year & $\begin{array}{l}\text { ENSO } \\
\text { proxy }\end{array}$ & $\begin{array}{l}\text { GD } \\
\text { typhoon }\end{array}$ \\
\hline 1747 & -1.20 & 1 & 1686 & 0.79 & 1 \\
\hline 1684 & -1.02 & 3 & 1905 & 0.80 & 1 \\
\hline 1879 & -1.01 & 0 & 1799 & 0.82 & 1 \\
\hline 1728 & -0.88 & 3 & 1639 & 0.84 & 1 \\
\hline 1870 & -0.87 & 7 & 1638 & 0.84 & 0 \\
\hline 1732 & -0.86 & 0 & 1617 & 0.86 & 2 \\
\hline 1652 & -0.85 & 4 & 1868 & 0.87 & 4 \\
\hline 1886 & -0.81 & 0 & 1803 & 0.87 & 0 \\
\hline 1727 & -0.81 & 1 & 1655 & 0.89 & 0 \\
\hline 1781 & -0.77 & 0 & 1790 & 0.92 & 0 \\
\hline 1892 & -0.76 & 0 & 1650 & 0.94 & 2 \\
\hline 1751 & -0.76 & 1 & 1745 & 1.01 & 2 \\
\hline 1653 & -0.71 & 5 & 1609 & 1.05 & 2 \\
\hline 1901 & -0.70 & 1 & 1815 & 1.06 & 1 \\
\hline 1819 & -0.70 & 5 & 1884 & 1.07 & 0 \\
\hline 1695 & -0.70 & 0 & 1791 & 1.07 & 3 \\
\hline 1667 & -0.69 & 2 & 1888 & 1.14 & 0 \\
\hline 1846 & -0.67 & 0 & 1746 & 1.15 & 0 \\
\hline 1818 & -0.66 & 4 & 1783 & 1.20 & 3 \\
\hline 1675 & -0.63 & 1 & 1725 & 1.27 & 1 \\
\hline Mean & & 1.9 & Mean & & 1.2 \\
\hline
\end{tabular}




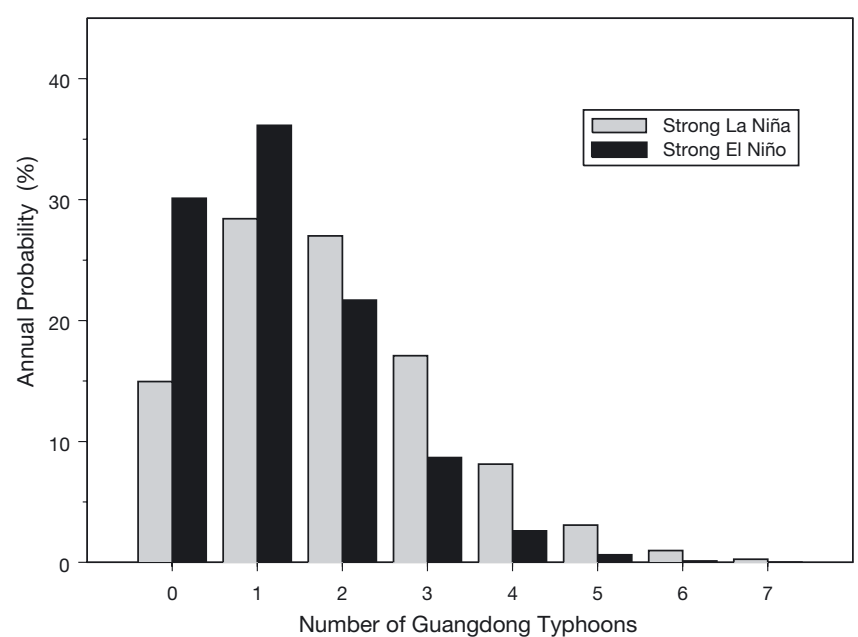

Fig. 6. Rate difference in Guangdong typhoon activity between extremes of the ENSO cycle translates into differences in the annual probability of activity. Here, we assume that the counts follow a Poisson distribution. Multiple typhoon hits are more likely during strong La Niña events

\section{SUMMARY AND CONCLUSION}

Climate factors related to the occurrence of typhoons in southern China were investigated. The work was motivated by the ENSO-typhoon hypothesis and by a recent hypothesis of an inverse relationship between the frequency of typhoons over northern China to those over the Guangdong Province in the south (Liu et al. 2001). The study makes use of the modern instrumental record of typhoons over the entire western North Pacific basin and documentary evidence of typhoons over Guangdong. Observational indices of ENSO, NAO, and the PDO are combined with paleoclimate proxies to examine climate factors related to typhoon tracks. The originality of this work rests with the independent examination of the hypothesis afforded by the documentary record of Guangdong typhoons spanning several centuries before the modern record.

First a cluster analysis was used to separate typhoons in the modern record into 3 categories based on track type. The categories include straight-moving, recurving, and north-oriented typhoons. Track types are similar to comprehensive subjective categories used by others. On an annual basis, the frequency of straightmoving typhoons is inversely related to the number of recurving typhoons; this is consistent with the hypothesis of Liu et al. (2001). The focus for the present work is on the straight-moving typhoons, as these are the ones that threaten southern China.

Grouping years by climate extremes provides evidence that ENSO might have an influence on this inverse correlation. Neither NAO nor PDO appear to play a role in coastal typhoon activity. A documentary record of typhoon landfalls in Guangdong and a proxy tree-ring record of SSTs over the equatorial Pacific were used to further examine this relationship. Using the 40 years of extreme values of the ENSO proxy ( 20 La Niña and 20 El Niño events) over 1600-1909, we found a $58 \%$ increase in the annual typhoon rate during La Niña events. Moreover, the probability of a year with at least 3 Guangdong typhoons is $35 \%$ during strong La Niña years compared with only $15 \%$ during strong El Niño years. This implies that ENSO modulates the poleward transport of heat and moisture through changes in tropical cyclone tracks (Wang \& Chan 2002).

When the equatorial Pacific SSTs are higher than normal (El Niño events), more typhoons originate east of $160^{\circ} \mathrm{E}$, and there is a tendency for typhoons to recurve toward higher latitude. In contrast, when the equatorial Pacific waters are colder than normal (La Niña events), more typhoons are noted over the South China Sea, and there is a tendency for typhoons to change little in latitude en route toward southern China. The present results lend support to the hypothesis that the odds of a typhoon striking populous southern China are conditional on the ENSO cycle.

Acknowledgements. We thank E. Fogarty and B. Bossak for their help with data collection and analysis. We thank the reviewers for a careful reading and useful comments. The research was partly funded by the Risk Prediction Initiative (RPI) of the Bermuda Biological Station for Research (RPI-99001 and RPI-96-048) and by the National Science Foundation (ATM-0086958 and ATM-9905329). Partial support for J.B.E. came from Florida State University's Program Enhancement Grant.

\section{LITERATURE CITED}

Black PG (1993) Evolution of maximum wind estimates in typhoons. In: Lighthill J, Zhemin Z, Holland G, Emanuel K (eds) Tropical cyclone disasters. Peking University Press, Beijing, p 104-115

Bouchard RH (1990) A climatology of very intense typhoons: or where have all the supertyphoons gone? 1990 Annual Tropical Cyclone Report, US Naval Oceanography Command Center, Joint Typhoon Warning Center, COMNAVMAIANAS, San Francisco, p 266-269

Chan JCL (1985) Tropical cyclone activity in the northwest Pacific in relation to the El Nino/Southern Oscillation phenomenon. Mon Weather Rev 113:599-606

Chan JCL (1994) Prediction of the interannual variations of tropical cyclone movement over regions of the western North Pacific. Int J Climatol 14:527-538

Chan JCL (2000) Tropical cyclone activity over the western North Pacific associated with El Nino and La Nina events. J Clim 13:2960-2972 
Chan JCL, Shi JE (1996) Long-term trends and interannual variability in tropical cyclone activity over the western North Pacific. Geophys Res Lett 23:2765-2767

Chan JCL, Shi JE (2000) Frequency of landfall over Guangdong Province of China during the period 1470-1931. Int J Climatol 20:183-190

Chan JCL, Shi JE, Lam CM (1998) Seasonal forecasting of tropical cyclone activity over the western North Pacific and the South China Sea. Weather Forecast 13:997-1004

Chen TC, Weng SP, Yamazaki N, Kiehne S (1998) Interannual variation in the tropical cyclone formation over the western North Pacific. Mon Weather Rev 126:1080-1090

Chia HH, Ropelewski CP (2002) The interannual variability in the genesis location of tropical cyclones in the Northwest Pacific. J Clim 15:2934-2944

Cook ER (2000) Nino 3 index reconstruction. International Tree-Ring Data Bank. IGBP PAGES/World Data Center-A for Paleoclimatology Data Contribution Series \#2000-052, NOAA/NGDC Paleoclimatology Program, Boulder, CO

Deser C, Wallace JM (1990) Large-scale atmospheric circulation features of warm and cold episodes in the tropical Pacific. J Clim 3:1254-1281

Dong K, Holland GJ (1994) A global view of the relationship between ENSO and tropical cyclone frequencies. Acta Meteorol Sin 8:19-29

Donnelly JP, Bryant SS, Butler J, Dowling J, Fan L, Hausmann N, Newby P, Shuman B, Stern J, Westover K, Webb T III (2001) A 700-year sedimentary record of intense hurricane landfalls in southern New England. Geol Soc Am Bull 113: 714-727

Elsner JB, Kara AB (1999) Hurricanes of the North Atlantic: climate and society. Oxford University Press, New York

Elsner JB, Kocher B (2000) Global tropical cyclone activity: a link to the North Atlantic oscillation. Geophys Res Lett 27: 129-132

Elsner JB, Liu Kb, Kocher B (2000a) Spatial variations in major U.S. hurricane activity: statistics and a physical mechanism. J Clim 13:2293-2305

Elsner JB, Jagger T, Niu XF (2000b) Shifts in the rates of major hurricane activity over the North Atlantic during the 20th century. Geophys Res Lett 27:1743-1746

Elsner JB, Bossak BH, Niu XF (2001) Secular changes to the ENSO-U.S. hurricane relationship. Geophys Res Lett 28: 4123-4126

Evans JL, Allen RJ (1992) El Nino Southern Oscillation modification to the structure of the monsoon and tropical cyclone activity in the Australian region. Int J Climatol 12:611-623

Franklin JL, Feuer SE, Kaplan J, Aberson SD (1996) Tropical cyclone motion and surrounding flow relationships: searching for beta gyres in omega dropwindsonde datasets. Mon Weather Rev 124:64-84

Goldenberg SB, Landsea CW, Mestas-Nunez AM, Gray WM (2001) The recent increase in Atlantic hurricane activity: causes and implications. Science 293:474-479

Gray WM (1984) Atlantic seasonal hurricane frequency. Part I: El Nino and $30 \mathrm{mb}$ quasi-biennial oscillation influences. Mon Weather Rev 112:1649-1668

Harr PA, Elsberry RL (1991) Tropical cyclone track characteristics and large-scale circulation anomalies. Mon Weather Rev 119:1448-1468

Harr PA, Elsberry RL (1995) Large-scale circulation variability over the tropical western North Pacific. Part I: Spatial patterns and tropical cyclone characteristics. Mon Weather Rev 123:1225-1246

Jagger T, Elsner JB, Niu XF (2001) A dynamic probability model of hurricane winds in coastal counties of the United States. J Appl Meteorol 40:853-863
Jones PD, Jonsson T, Wheeler D (1997) Extension to the North Atlantic Oscillation using instrumental pressure observations from Gibraltar and south-west Iceland. Int J Climatol $17: 1433-1450$

Jury M (1993) A preliminary study of climatological associations and characteristics of tropical cyclones in the SW Indian Ocean. Meteorol Atmos Phys 51:101-115

Kentang L (2000) An analysis of the recent severe storm surge disaster events in China. Nat Hazards 21:215-223

Krishnamurti TN, Bedi HS, Yap KS, Oosterhof D, Rohaly G (1992) Recurvature dynamics of a typhoon. Meteorol Atmos Phys 50:105-126

Lander MA (1994) An exploratory analysis of the relationship between tropical storm formation in the western north Pacific and ENSO. Mon Weather Rev 122:636-651

Lander MA (1996) Specific tropical cyclone track types and unusual tropical cyclone motions associated with a reverse-oriented monsoon trough in the western north Pacific. Weather Forecast 11:170-186

Lander MA, Guard CP (1998) A look at global tropical cyclone activity during 1995: contrasting high Atlantic activity with low activity in other basins. Mon Weather Rev 126: $1163-1173$

Landsea CW, Gray WM, Mielke PW Jr, Berry KJ (1992) Longterm variations of western Sahelian monsoon rainfall and intense U.S. landfalling hurricanes. J Clim 5:1528-1534

Li C (1986) El Nino and typhoon action over the western Pacific. Kexue Tongbao 31:538-542

Liu Kb (1999) Millennial-scale variability in catastrophic hurricane landfalls along the Gulf of Mexico coast. In: Preprint Volume of the 23rd Conference on Hurricanes and Tropical Meteorology, January 10-15, 1999, Dallas, TX. American Meteorological Society, Boston, p 374-377

Liu Kb, Fearn ML (1993) Lake-sediment record of late Holocene hurricane activities from coastal Alabama. Geology 21:793-796

Liu Kb, Fearn ML (2000) Reconstruction of prehistoric landfall frequencies of catastrophic hurricanes in NW Florida from lake sediment records. Quat Res 54:238-245

Liu Kb, Shen C, Louie Ks (2001) A 1000-year history of typhoon landfalls in Guangdong, southern China, reconstructed from Chinese historical documentary records. Ann Assoc Am Geogr 91:453-464

Mantua NJ, Hare SR, Zhang Y, Wallace JM, Francis RC (1997) A Pacific interdecadal climate oscillation with impacts on salmon production. Bull Am Meteorol Soc 78:1069-1079

MathSoft (1999) S-Plus Guide to Statistics, Vol 2. Data Analysis Products Division, MathSoft, Seattle, WA

Nicholls N (1984) The southern oscillation, sea surface temperature, and interannual fluctuations in Australian tropical cyclone activity. Int J Climatol 4:661-670

Pan Y (1981) The effect of the thermal state of eastern equatorial Pacific on the frequency of typhoons over western Pacific. Acta Meteorol Sin 40:24-32 (in Chinese)

Ramage CS, Hori AM (1981) Meteorological aspects of El Nino. Mon Weather Rev 109:1827-1835

Revell CG, Goulter SW (1986) South Pacific tropical cyclones and the southern oscillation. Mon Weather Rev 114: $1138-1145$

Sandgathe SE (1987) Opportunities for tropical cyclone motion research in the northwest Pacific region. Naval Postgraduate School Paper NPS-63-87-006, Department of Meteorology, Naval Postgraduate School, Monterey, CA

Saunders MA, Chandler RE, Merchant CJ, Roberts FP (2000) Atlantic hurricanes and NW Pacific typhoons: ENSO spatial impacts on occurrence and landfall. Geophys Res Lett $27: 1147-1150$ 
Wang B, Chan JCL (2002) How strong ENSO events affect tropical storm activity over the western North Pacific. J Clim 7:929-948

Wu CC, Kuo YH (1999) Typhoons affecting Taiwan: current understanding and future challenges. Bull Am Meteorol Soc 80:67-80

Editorial responsibility: Robert Davis,

Charlottesville, Virginia, USA
Wu G, Lau NC (1992) A GCM simulation of the relationship between tropical-storm formation and ENSO. Mon Weather Rev 120:958-977

Zhang Y, Wallace JM, Battisti DS (1997) ENSO-like interdecadal variability: 1900-93. J Clim 10:1004-1020

Submitted: March 24, 2003; Accepted: July 14, 2003

Proofs received from author(s): September 25, 2003 